\title{
In Iron Light: Eeriness, Decomposition and Social Movements
}

(PENULTIMATE VERSION - Feb 2016. Final version in Culture and Organisation DOI: $10.1080 / 14759551.2016 .1151425)$

\section{Dr Gareth S. Brown (University of Leicester)}

In the UK, the recent flourishing of organised resistance against austerity and the dominance of the free market over all aspects of life has done little to buck an overall trend of decreasing membership in political parties and similar organisations. Few informal organisational forms on the Left have faired better. However, these diminishing structures have certain key characteristics in common and there are suggestions of alternative political forms emerging in their stead. This article argues that such periods of decomposition, far from being an indication of failure, are an important and desirable element of social movement that can and should be deliberately factored in to political organising. Building from the notion that the basis of social change is the ability to move out of existing institutions, the article explores three methodologies of decomposition that bridge the divides between mythology, poetry, and political theory: Negative Capability, Eeriness, and the surrealist game.

Keywords: Organisation, Movement, Decomposition, Eeriness, Surrealism

\section{Introduction}

'Perhaps the absence of myth is the ground that seems so stable beneath my feet, yet gives way without warning' (Bataille 2006, 48)

Think back to the period from 2010 to 2013 . For those engaged in left-wing politics in the UK this quadruplet of years was a tumultuous seesaw. 2011 saw the Occupy 
movement that had emerged in New York take the stage first (briefly) in Manchester and then outside St. Paul's Cathedral in London. At the same time a still fairly wellorganised student movement that had erupted the year before to fight the imposition of university fees continued to organise in and around campuses. We experienced too the 'summer of rage' where riots broke out in several major cities. Coming hot on the heels of the 'Arab Spring' as it did, many people cautiously hoped this literal and metaphorical conflagration, whilst problematic in many respects, would be another droplet flowing into a growing and more coordinated river of anti-austerity dissent. And indeed it was (as I have argued with others elsewhere [Brown et al. 2013]). However, if such a river continued to flow then it did not do so with the force that had been enthusiastically envisaged. By the following year the student movement had flagged (suffering from the same curse that had affected previous student movements - the three year tour of duty wherein the normal period of undergraduate study governs the duration of students' proximity to the site of struggle.), the riots appeared as an anomaly, a new and emboldened Occupy movement did not retake the squares. A year later, after an astonishingly badly handled response to an allegation of rape against a member of its central committee, the Socialist Worker Party, one of the largest radical left parties in the UK, began shedding members by the hundreds (Steel 2013). The Socialist Party too was in rapid decline after a strikingly similar scandal (Townsend 2013). These parties have not yet recovered and there is little reason to suspect they will do.

It would be tempting to treat the above as separate fields of analysis. Whither now the 'horizontalist' movements of the last few decades with their loose networks of temporarily constituted bodies and rejection of hierarchies? Whither now the Trotskyist and orthodox Marxist parties of the twentieth century with their hefty, centralised 
structures? Such projects would yield different and very specific results. However, I am more interested here in what is common to this notable period of decomposition. It is a commonality that appears even more significant when one places it in the context of a major and several decades long decline in membership of the mainstream political parties and unions. What appears overall is an exodus from massifying forms of organisation.

There are important questions that follow from this set of observations that I am not going to answer. The most obvious is 'what comes next/instead?'. Although I refer below to several scholars' thinking on this question I do so only in order to further the central investigation of this article: how can political decomposition be productively organised? To that end, I begin with a more detailed look at the facts of the exodus from massifying organisation that I have introduced above and explore the question of why this has come to be considered an undesirable phenomenon by certain sections of the political left. Contrary to this negative value judgment, I suggest (drawing on Castoriadis $[1987,1997])$ that such processes are necessary, desirable, and propulsive elements of radical social transformation.

From there I proceed towards an exploration of methodologies of decomposition. I concentrate on three of these. The first is Negative Capability, drawn from the political theory of Roberto Mangabeira Unger (2001) but first developed as a concept by the poet Keats (1968). In this section I elaborate Unger's use of the concept in relation to rigid institutions and what he calls 'False Necessity'. The second methodology is Eeriness. I take this directly from Lewis Carroll (1987) for whom it describes a means via which one might meet with fairies. I argue that the notion of something existing just outside the field of vision that eeriness encapsulates is one that is common to many myth narratives. The last methodology I look at is the surrealist 
Game with its emphasis on objective chance as the basis of revolutionary transformation. I trace the development of this idea from early works by André Breton (2007) and Louis Aragon (2003) to formulations by Gerashim Luca and Trost (2001) and Breton's later invocation of the 'new myth' of the Great Transparent Ones (2007).

The sequence in which these three methodologies are explored corresponds, perhaps somewhat counter-intuitively, to the degree to which concrete suggestions for forms of political organisation can be drawn from them. Not just any forms of course; forms that address our central problematic around decomposition and recomposition. The thread that winds all three together is the notion that the engine of deliberate social transformation is not constituted by designing sturdy new institutions and moving into them but by creating the conditions from which new temporary institutions can continually emerge. In Unger, then, we find a carefully constructed theory of the societal importance of experimentalism and 'disentrenchment' but without a considerable amount of detail about what such experimentalism might look like. Conversely, Carroll offers detailed instructions for the affective production of eeriness but does so on a mythofantastical terrain (although this is not akin to saying that we cannot analogically derive useful insight from his words). The surrealist model of gameplay however (and in particular its development after the surrealists encounter Marxism) begins to suggest structures that can be related to those we find in contemporary social movements. Drawing on the examples of the dissolution of Class War in the late nineties and the more recent phenomena of 'Corbynmania', this essay ends by elaborating on these relationships. 


\section{The age of the mass organisation is over}

When I refer to mass organisations, I mean those with a rivalrous character and definable boundaries so that individual actors can be said to be outside or inside the organisation. I don't intend there to be any particular value-judgment attached to the idea of rivalrousness but rather use it as descriptive of a thing of which there can be only one, that tends towards a single, unified whole by absorbing or destroying similar bodies around it. I employ mass in this way because I think it's important to uncouple it from the idea of numerousness, or of largeness. A mass organisation can be tiny (and often is), and there is far more numerousness, or largeness in the social movements around these organisations. I would link the word instead to the idea of massification, the production of a discrete object, collecting around a single point - be that single point a constitution, set of policy documents, leadership, or system of ethics. The rivalrousness of such organisations can be complicated by their day-to-day existence in a relationship of debate or struggle with other rivalrous organisations that is pragmatically treated as irresolvable (at least for the foreseeable future). This does not however rid them of their massifying form. An example would be the UK parliamentary system wherein the existence of more than one party is accepted whilst at the same time each party works to increase their own power by diminishing the share held by other parties.

It would be a mistake however, to attribute the term only to formal membership organisations. The anarchist milieu, although not a political party, is an example of a different form of massifying organisation in that it collects around a central ethical model about how to live. The failure to subscribe to this model places one on the outside and renders the anarchist identity of the outsider null and void. The milieu also 
seeks to create anarchists/spread anarchism through a variety of means and can therefore be considered an expanding or recruiting body.

As political organisations, mass organisations are distinct from the organisational forms that we find in the market in that the central conditions for their growth are different. Their hypothetical upper limit is the entire global population. Social movements are very different. Far from being bodies with boundaries, they are things that happen, the movement of social relations (Free Association 2011). As opposed to the positive charge of a magnetic centre comprised of offices, hallmarks, ethical systems, they are instead a fluid that collects around shared problematics (Milburn 2011). Social movements continually produce political organisations. Such organisations may remain intimately linked with the movement that produced them, completely detach, or be somewhere between the two.

The last decade, and in particular the last five years, has seen a remarkable decline in mass organisations and particularly in political parties. In the UK, figures published two years ago show the membership of the main political parties dropping from more than $4 \%$ of the electorate in 1979 to a current figure of less than $1 \%$. This decline has been particularly acute in the Labour party which, despite still having the largest membership base, had close to 10 times the number of members at that time. The steepest decline has been in the last decade. (UK Gov. 2013) During the same period, union membership has almost halved from over 13 million to just over 7 million and continues to drop (UK Department of Business \& Innovation 2012). Though shrouded in mystery and misinformation, membership of larger left revolutionary parties is in rapid decline also. The Socialist Worker Party for example, although sometimes 
attributed with a membership figure in the thousands, is believed by many ex-members to have a steadily decreasing membership possibly as low as a few hundred. ${ }^{1}$

At first glance there appears to be a recent counter-trend represented by phenomena such as the Green Surge and Corbynmania, where, after mobilising largely through social media, tens of thousands joined (or registered as supporters of) the Green and Labour parties respectively in order to support anti-austerity policies and candidates. This is a fascinating development but it would be a mistake to think of it as sea-change in specific terms of participation in mass political bodies. To begin with, the upsurge, although remarkable in terms of the change from the previous year still comes nowhere near to matching the levels of participation seen in the 70 s. Furthermore, it has been suggested that many of those who have recently joined the Labour Party are the same as those who joined the Green Party only 6 months earlier. ${ }^{2}$ Groundless paranoia about sabotage and entryism aside, there are two possible ways we might think of this. The more optimistic is that these are the seeds of a new, more politically mature generation of social movements that are more astutely able to operate in a fluid partnership with institutional actors. The less optimistic is that this recent electoral turn, as the editors of bamn have suggested, is simply what a movement does in the absence of a strategy (bamn Editorial Group 2015).

${ }^{1}$ It is very difficult to find reliable sources around this issue. However, an internal debate on the subject can be found recounted in the document 'SWP conference minority position and reply by Central Committee' (Socialist Worker Party 2014)

${ }^{2}$ The information one would require in order to demonstrate this is not available. It has however been the subject of wide speculation (see Joffe 2015 for example). Tellingly, the Guardian reported that $8 \%$ of Green Party candidates in the last election had joined the Labour Party as part of the recent influx (Sparrow \& Mason 2015). 
It isn't only the more formal structured organisational forms that have faltered of late. Occupy, arguably the UK's most significant recent grass-roots movement, also failed to produce the kind of lasting organisational networks that its predecessors the alter/anti-globalisation movement and the Camp for Climate Action had produced. Commentary on Occupy has ranged from enthusiastic (but by now somewhat impotentseeming) declarations of its evidencing a new 'anarchist turn' (see Simon Critchley's introduction in Blumenfeld et al. 2013) to a short-sighted notion that for it to politically mature would necessitate it taking the form of (or being absorbed by) a political party (such as the argument put forward by Jodi Dean in The Communist Horizon [2012]). Both of these arguments miss Occupy's character as a shift away from massification either that around a formal political organisation or that around a system of morality such as anarchism. We can see in it both the end of the cycle of struggles that began with the Carnival Against Capital in London on June18th 2000 and the beginning of something new. That something new may be, as Rodrigo Nunes has argued in Organisation of the Organisationless (2013), a shift towards 'forms of action' occupying the nodal position that individuals, affinity groups, and offices have occupied in previous political formulations. Nunes refers to this as 'distributed leadership', an informal system where groups or individuals innovate and experiment with forms of action that either 'take off' or don't and which, if they do, are subsequently modified and developed by other groups and individuals who may have no organisational or personal connection to the first. Indeed, this would fit well with the thesis that the development of the Green surge into Corbynmania indicates that the new centres of orbit are constituted by ideas rather than by organisational bodies as of old.

Nunes offers us a plausible proposition. However, I don't wish to deal in this paper with the question of 'what comes next?' but with the idea that organisational 
decomposition is a necessary and welcome component in getting there. So much so, that rather than being left to happen by accident, it demands a serious consideration of possible methodologies of decomposition in order to ensure a perpetual cycle of decomposition and recomposition.

\section{Body-Horror}

Official statements on the health of shrinking mass organisations may typically be full of bravado but it is easy to imagine that to have given one's life over to the building and defence of an organisation that one considers to be the mass organisation of the oppressed, only to see that body crumble, must be personally devastating.

There is a compelling logic to the idea that massification is necessary to combat capitalism. On the one hand we could point to analyses such as that offered by the Institute of Precarious Consciousness (2014) who theorise that different phases of social organisation come with dominant affects and that contemporary Neoliberalism corresponds to one of generalised anxiety. It makes sense that in this context structures capable of resisting change, of weathering storms, steadfast invariants facing-off against a cascading waterfall of profit-oriented progress, should be attractive and psychologically important. Away from the realm of affect, we could turn too to Leninist dismissals of the 'horizontalist' loose network styles of organising prevalent in social movements since the 1990s. This critique (the more sophisticated permutation of which can be found in Žižek 2003) holds that such networks are merely a reflection of the domination of the market where individual actors can pick and choose from an everchanging shopping arcade of campaigns and temporary organisational bodies. In this imaginary the left, as a movement in opposition to the neoliberal market requires a mass 
organisation as central unified object of transference for the desires of the working class.

Such a critique however, not only understates the differently massifying character of those horizontalist forms but also overstates the fluidity of the market. As Max Haiven (2014) has adeptly argued, the crisis of the imagination, the failure to create new and viable social forms is very much grounded in the economic functionality that exerts a rigor mortis grip upon the parameters of the market. In other words the freedom to choose and to act that we experience under neoliberalism is a freedom only within a narrow canal upon the fuller surface of the possible. The market is already a central, unified object of transference but for a wholly different set of desires. The Leninist Party, though in opposition to it, is perhaps closer to providing its mirror image.

Correspondingly, we must acknowledge that invariance, ossification in an organisational structure, can be at least as damaging as its failure to hold together. The history of political organisation is peppered with the creation of bodies in which energies are channelled endlessly towards the maintenance of myth or dogma - from the much maligned spin-focus of post-Blair UK parliamentary politics, to the alleged discouragement of reading anything outside 'the IS [International Socialist] tradition' in the SWP (Jepps 2013), to the ruthlessly policed privilege imaginaries of contemporary identity politics milieus. But the future never seems to grow into these tailored outfits, and the constellations of the possible that they represent drift further and further off from the shoreline of the present. The anchoring structures that dogmatic political organisations can form can actually serve to trap us outside the otherwise fluid experience of being alive. They can impede our ability to build from everyday life, quite literally fortifying against social movement, which, if it must do anything, must move. 
We may end up using a mass organisational form such as the party to combat anxiety only to produce a strange, collective dissociation instead.

Dynamism of social movement is important. In the context of political organisations this maps onto the ability to morph, expand, contract, deconstitute and reconstitute. It involves developing the ability to incorporate ideas and experiences from places wholly outside the traditions from which they formed, developing the ability to dissolve dogma in the flowing liquid of the everyday. For the philosopher and communist Cornelius Castoriadis, the very basis of Politics is this dynamism, constituted as the ability to call into question existing structures and institutions (Castoriadis 1991). Castoriadis is a useful figure to bring into the present discussion because the flaws in his theories suggest a potentially productive set of hidden problematics. Castoriadis is most familiar as a theorist of the Socially Instituting Imaginary. He writes about the 'active' or 'creative' imagination as a social faculty that operates as the engine via which individuals are both instituting of and instituted by society (Castoriadis 1987, 1997). The greater body of his work then is concerned with composition rather than decomposition, whilst the crux of his political project is the reverse. Castoriadis never fully bridges this gap on account of his construction of social institutions as being essentially monadic, meaning that it is not possible to act outside them. The idea, therefore, that decomposition could be a deliberate act is something he treats with great caution and as an open question that he never resolves (Castoriadis 1997).

How then can these periods of decomposition necessary to political dynamism be achieved in a way that is collective, reciprocal, ongoing, and propulsive rather than being left to happen through accident or failure? The political and juridical theorist Roberto Mangabeira Unger (2001) has written much on this process. Where I have used 
the term 'decomposition', Unger's favoured term is 'disentrenchment' (or sometimes 'denaturalisation'), and what we might call, extrapolating from Castoriadis' work, a process of 'social imaginary deinstitution', Unger refers to as 'negative capability'. I want to take some time to consider this concept as it is the bridge that takes us from political organisation to myth and back again. As we move into this consideration of Unger, so too do we shift the focus of this article one stage further: from the observation that political decomposition is a contemporary trend, to the argument that it is a necessary and desirable phenomenon, to the question of how decomposition can be organised.

\section{Negative capability}

The term negative capability originates from a letter that the poet Keats wrote to his brothers on the winter solstice of 1817 . He invokes the idea in order to try to describe the special abilities of those he considers great writers. It means, he tells them, being 'capable of being in uncertainties, mysteries, doubts without any irritable reaching after fact \& reason' (Keats 1968, 40-41). Unger (2001) employs the term on a socio-political terrain and as a result doesn't need to subscribe to Keats' association of doubt with a deferment (or abandonment) of reason. For Unger, it corresponds instead to the collective removal of faith and certainty regarding social and political institutions.

We need to understand negative capability in Unger's work via its relationship to two other concepts: False Necessity and Formative Context. False necessity is that to which Unger's critical project is opposed. It refers to naturalised or deterministic models of human society - the idea, on the one hand, that one form of socialisation is specifically that for which human beings have evolved and, on the other hand, that certain forms of society necessarily follow from others. For Unger, the variety of 
possible social arrangements tends towards infinity. However, that does not mean that any arrangement could follow on from any other arrangement. He is meticulous in arguing that future societies are always built from and within present ones, carrying them within their kernels. Each of these societies is a Formative Context, and these are, for Unger, institutional or imaginative arrangements. From this we can conclude that the success of the struggle against false necessity can be measured in the number of possible future formative contexts that can be produced from the present one. Unger argues that the capacity of a particular formative context to produce a multitude of possible future arrangements is connected to its capacity to facilitate negative capability. Negative capability is for Unger, as it is for Keats, the ability to doubt the fixedness of an encountered situation and is constructed as a process of 'disentrenchment':

'[Disentrenchment] enables us to recognize more fully the conflicting conditions of self-assertion: the need to participate in group life and to avoid the dangers of subjugation and depersonalization that attend such engagement. This more successful reconciliation of the enabling conditions of self-assertion represents another side of empowerment. But the most straightforward sense in which the disentrenchment of formative contexts empowers people lies in the greater individual and collective mastery it grants them over the shared terms of their activity. Because this range of forms of empowerment is achieved by creating formative contexts that soften the contrast between context-preserving routines and context-transforming challenge, it might be called negative capability' (Unger 2001, 36-37)

Unger is quite clear that the move towards societies that enable greater levels of negative capability is not the same as move towards ever-greater levels of 
indeterminacy. Rather, there are 'certain specifiable features' wherein 'some ways of organising $[\ldots]$ lie farther along the spectrum of disentrenchment, and succeed better at producing negative capability, than others' (ibid. 37). Indeed, Unger develops an idea of 'stability' that is opposed both to total indeterminacy and to rigidity, arguing that the unending development of negative capability is a requisite of a stable formative context. Furthermore, Unger suggests that such coherence cannot be sustainably modular in that clusters of institutional arrangements don't easily work together unless they 'embody similar levels of emancipation from false necessity' (ibid. 164)

One of the criticisms levelled at Unger (for example by Fish [1990]) is that he neglects the all-important question of how one actually does negative capability. This is neither entirely fair nor entirely unfair. False Necessity: Anti-Necessitarian Social Theory in the Service of Radical Democracy, for example, is full of historical illustrations of the movement from one formative context to another through processes that demonstrate the concept. More broadly, Unger calls explicitly for 'political and economic institutions and styles of personal association accelerating experimentalism in every aspect of social life' $(2001,602-603)$. It is probably unreasonable to expect Unger to have told his readers which specific collective, political projects are those that nurture negative capability and how precisely they might do it, particularly in the context of his argument that such things must be experimental rather than prescriptive. However, whilst agreeing with this pro-experimentalist position unreservedly, we may in this article be able to go some short way further into exploring the question of how one might enact collective experiments in productive doubt. Such an exploration though demands that we first provide a richer backdrop to the idea in order to demonstrate that far from simply being the product of Unger's imaginative rereading of Keats, negative 
capability must be situated within a larger field of methodologies, a field occupied in no small part by myth and poetry.

\section{Eeriness}

Firstly, I want to explore the idea of 'eeriness' as employed in Lewis Carroll's Sylvie and Bruno (1987). The unconventional narrative of this book makes it hard to give a straightforward synopsis. The story concerns at some point a narrator/protagonist's encounters with the title characters, who are siblings, who at some point become, or are revealed as, or are simply portrayed as, fairies. For most of the book the lives and concerns of these title characters are quite separate from those of the narrator, and it is implied that the long passages concerning their antics and those of fellow denizens of Outland are recounted to us as dreams whilst he continually drifts off, seemingly whenever seated (much like the dormouse in Wonderland, this character is truly extraordinary in his propensity to fall asleep). Later on though, these waking and sleeping worlds begin to merge. The protagonist describes the production of this merger:

\footnotetext{
'The first rule is, that it must be a very hot day - that we may consider as settled: and you must be just a little sleepy - but not too sleepy to keep your eyes open, mind. Well, and you ought to feel a little - what one may call "fairyish" - the
} Scotch call it "eerie" and perhaps that's a prettier word' (Carroll 1987, 338)

Despite a certain assonance, eerie and fairy do not appear to share a root. Whilst the source of the word fairy is thought to lie in the Greek furies, eerie comes to us through 
an etymology that passes through a whole host of European languages usually with a meaning relating either to fearfulness, cowardliness, or a more nondescript 'bad'. The everyday use of the term will suit just fine as a starting point for its deeper elaboration though. We talk of eeriness as a sense of things being weird, fearfully uncanny, or not right. It is a word we associate with being scared, with feeling that we may come to harm in ways that it is quite impossible to articulate. With Carroll, I wish to expand away from these negative connotations. Carroll's eerie is about seeing through the act of unseeing. It is about deliberately unsettling an understanding of the whole in order to allow for the discovery of elements of the real not previously incorporated in that whole. Following from this we might replace not right with not fixed and posit instead of 'fearfulness' a sort of productive paranoia.

The idea that Carroll wished to convey with the term is certainly not of his own invention. There is a long association of fairy-folk and other forest-dwelling folkloric characters and cryptids with crepuscular shifts, with the period of iron light where the evening greys succumb to the orange oxidation of dusk or contrariwise with dawn's return journey. This may in part be to do with the fact that this represents the time of strange encounters with the non-mythical native wildlife of much of western Europe, many of which are either nocturnal or are themselves crepuscular. We diurnal beasts often experience these chance meetings as uncanny or special. Sightings of bats, foxes, owls, and badgers remain moments of note for many of us for the whole of our lives. If these incredible animals come out after we ought to be sleeping, what else stalks the night? In thermodynamics, the point at which matter changes from one state, such as liquid, to another such as gas is known as phase transition. For humans, these crepuscular moments are perhaps something like the phase transition of the imaginal. The softening of our vision, the lengthening of shadows that wreaks havoc on the 
geometries and geographies with which we had felt secure mere hours ago, allows for radically different interpretations of our physical environments. Whilst not wishing to invoke the ire of folklorists who caution against the drawing of broad commonalities between stories from radically different parts of the world, it is certainly worth mentioning that other beings that we might think of as fairy equivalents also occupy spaces that are somewhat hostile to humanity and rich in nocturnal life, such as the djinn of the Arabian deserts or the curupira in the forests of Brazil.

Mythology that hinges on the idea of an otherness just out of sight, or not directly perceptible, is not limited to fairy lore though. A great example (and one that provides a link with surrealist methodology that we shall consider next) is the mythical city Na-Akoja-Abad that we encounter in Islamic mysticism. A major source for this mythology is once again poetry, in particular the Sufi poet Sohrevardi (Corbin 1964). Na-Akoja-Abad, the Islamologist Henry Corbin (ibid.) tells us, is a 'place that is no place' that can be found on the convex surface of the sphere that contains the whole of reality. What is interesting about this mythical city is that it isn't simply 'no place' in the sense that we might describe a fictional world as being. It is, more specifically, found in a non-Euclidean geometric space. Movement to and through the city is not a question of distance but of resemblance or, put differently, of analogy. In this sense, just like Carroll's fairies, Na-Akoja-Abad is neither close to nor far from us. Reaching it as a matter of a modal rather than a geographic change. The eeriness that one must cultivate in order to reach this mystical topography is related to the suspicion that the elements of one's environment may be revealed to be more than they seem through the operation of analogical expansion. We will see in the next section that this is also the operation that underlies surrealist method. 
As with Unger's (2001) negative capability, these mythological treatments of moving into otherness, of deinsituting or decomposing, suggest that what lies at the heart of these methodologies is not imagining a new space (or a new formative context in Ungerian terms) but creating the conditions from which a new space might emerge. Clearly though, it is not sufficient to insist that political organisation must adopt a disposition of eeriness in order to avoid ossification and dogma. In order to address this problem, I want to turn to surrealism as a (much misunderstood) set of practical methodologies that, whilst being grounded in poetry, are weaponised for the purpose of the revolutionary transformation of society.

\section{Games of Chance}

Much like describing 'what communists think' or even 'what Marxists think', introducing surrealism is no easy task not because it is particularly complicated but because it is a system of thought that has developed over what is now almost a century and retains many internally contested and conflicting ideas. There are, however, key threads that we can watch in development through a handful of carefully chosen texts, which will serve not only to illuminate surrealist practice but also further the current investigation.

Both Breton's Manifesto of Surrealism (2007) and Aragon's A Wave of Dreams (2003), originally published in the same year - 1924 - during the movement's so-called 'period of trances', concentrate on dreams. An early articulation of surrealism offered by Breton $(2007,14)$ is this: 'I believe in the future resolution of these two states, dream and reality, which are seemingly so contradictory, into a kind of absolute reality, a surreality, if one may so speak'. It is largely due to the overemphasis on Breton's first 
manifesto (for a long time one of the only widely available texts of surrealist theory in English translation) that one occasionally encounters surrealism as a sort of 'psychoanalytic art' or as a project centred on the meager ambitions of writing or painting the scenes of the unconscious. This would be to mistake a tactic for an aim however.

In Aragon's Wave of Dreams (2003) from the same period we still see the dream emphasised but in contrast with Breton, Freud is downplayed here. In this work it is clear that neither the dream, nor the unconscious, are the real focal points of this early stage in surrealist activity. Rather they are aspects of gameplay (which I will return to) for the purpose of producing fertile ground for the chance to intervene. More broadly, the surrealist interest in the dream is as the source of desires and ideas that seem to have fluid and often oppositional relationships to those of established social institutions ${ }^{3}$.

Breton's secondary focus in the first manifesto is on automatic writing, the importance of which he talks about in the context of a (friendly) critique of the poet Paul Reverdy's claim that 'the image $[\ldots]$ cannot be born from a comparison but of a juxtaposition of two more or less distant realities' (cited in Breton 2007, 20). Breton counters this with his suspicion that Reverdy's poetic methodology cannot possibly be the result of conscious premeditation:

'The value of the image depends upon the spark obtained; it is, consequently, a function of the difference of the potential between the two conductors. When the spark exists only slightly, as in comparison, the spark is lacking [...] Now, it is not

\footnotetext{
${ }^{3}$ Of course, there is only so far that one can go with that argument and as Trost argued in Vision dans le Cristal dreams are very much subject to the values of the waking world (or 'reactionary diurnal remnants' [cited in Luca \& Trost 2001, 39]).
} 
within man's power, so far as I can tell, to effect the juxtaposition of two realities so far apart' (ibid. p. 37)

This spark might be thought of as synonymous with what Breton also calls 'the marvellous' and it is this latter term that became a mainstay of surrealist terminology. Crucial is that this spark/marvellous is elsewhere. There is no sense in the surrealist marvellous that it is the truth behind the façade. It represents instead a permanently distant horizon revealing the limitations of what we might call with Unger the current formative context. We can see a similar process in analogical juxtaposition. Take, for example, Lautréamont's famous phrase (beloved in the early surrealist movement): 'He is fair $[\ldots]$ as the chance meeting on a dissecting-table of a sewing-machine and an umbrella' (Lautréamont 1998, 193). Lautréamont is describing a particular (human) character in his book. He is also describing a bat, a bat constructed accidentally by an encounter between three different objects that together manifest a certain batness, a batness in which the beauty of Lautréamont's character is revealed. Each of these imaginal landmarks transforms the total terrain upon which they appear. The relationship is not a closed one between human, bat, umbrella, sewing-machine, and operating table, but a total one that affects the movements of all other objects. It is not that, to simplify the particular associative network in play, bat and umbrella are now transformed into a unified third thing, the batumbrella, but that the previously closed categories of bat and of umbrella are now torn open. I am drawn out from bat towards umbrella, out from umbrella towards bat. More importantly though, each has destabilized the substance of the other, exponentially multiplying the number of possible avenues out of bat, the number of possible avenues out of umbrella, and irrevocably installing a sense of undeniable and compelling doubt within each. The 
whole constellation of the possible has shifted, never to return to its previous shape.

There is a recurring intimation in both Breton's Manifesto and in Aragon's A Wave of Dreams that surrealist activity cannot be fully deliberate and we find this echoed in both Castoriadis, who is pessimistic about the idea of active imaginal decomposition (1997) and in Unger, who cautiously tells us that negative capability may be developed 'more or less' consciously (Unger 2001, 36). This is crucial and the underlying argument (applicable in each case) is obvious. If that which we have socially instituted produces our conscious experience of the world, then it cannot be logically possible to consciously think outside it. It is not hard to reconcile the paramount importance of chance and accident with this early phase of surrealist activity, taken up as it was with small group experiments that valorized compulsion, passion, and (just as we saw in Keats) the circumvention of reason.

When the surrealists discover Marxism and immerse themselves in active social struggle however, yet still retain this absolute dedication to objective chance; we can no longer avoid being thrown into a set of problematics around social institutional decomposition. Put simply, the revolutionary project of surrealism is not the replacement of one set of social (and ontological) arrangements with another, it is the creation of the conditions from which further social arrangements might emerge through the destabilising (disentrenching) of the current ones - just as we have seen in Unger. This is a perpetual project, not a temporary one with a fixed Utopian future ushered in by the proletarian seizure of the state (which, to be clear, was something of which Breton and his comrades were in favour) at the end of it, 'a horizon that continually flees before the walker' (Aragon 2003, 5).

The form taken by this project (and although I proceed with some caution I think I would not be incorrect in attributing this form to all surrealist activity) is the game. In 
Beyond the Pleasure Principle (1962) Freud describes a game played by his young nephew which he calls 'Fort! Da!' (meaning ‘Gone! There!') This game would simply consist of allowing a reel around which a piece of string was tied to roll away with an exclamation of 'Fort!' and then drawing it back in again with an exclamation of 'Da!' For Freud, this serves to illustrate that the basis of the game is the interplay of anxiety and relief with the most important element being that everything returns to the way it was before the game began. In short, the game is a form of activity completely without consequence (Freud 1962,15-17). It is from this notion that we derive the association of game with frivolity, futility, or non-seriousness.

The surrealist game could not be more opposed to Freud's model. It is instead, constructed around the notion that nothing is the same afterwards and targeted specifically at change. It certainly retains the character of play (and is often both joyful and humorous) but it is a form of play that no longer appears as the opposite of seriousness. The point of the surrealist game is to construct entry points for the intervention of objective chance understood in the Hegelian sense of that which disproves determinism and forces open new fields of potential. There are certain areas of surrealist investigation in which the manifestation of this approach is very clear (for example the interest in found objects, abandoned or ruinous spaces, and in subverting tools traditionally used for divination such as the Tarot). More often than not, the collective and inter-subjective elements of surrealist practice are derived from the fact that, from the perspective of each individual participant, every other participant acts as a conduit through which objective chance intervenes. An obvious example of this would be the early game 'Exquisite Corpse' wherein a textual clause written on a piece of paper by one player will be followed by another written by the next who is either in part 
or in full unaware of the previous one. ${ }^{4}$ Even the experiments with the unconscious performed by solitary surrealists can be thought of as attempts at collective games between different parts of a split self. But this game approach goes beyond those activities that, with a brief introduction to the idea of games as processes of change, it is quite easy to understand as games. It is also, for surrealists, the basis of social struggle.

In Breton's Second Surrealist Manifesto (2007) he recognises a great affinity with the surrealist project in Marx's inversion of Hegel's dialectic . However, the surrealist commitment to an eternal process of unfolding, what we might call a radical anti-institutionalism (not in the sense of a refusal to engage with, or participate in the creation of, institutional forms but in the sense of a commitment to their fluidity) quickly made their relationship with the Third Communist International a fraught one.

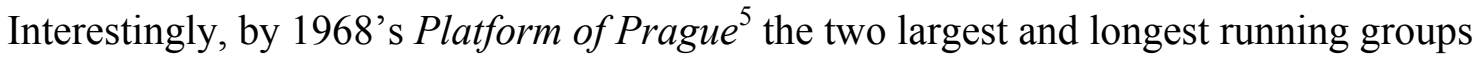
in the surrealist movement, by this time long established as critics of Stalinism, were celebrating the diminishing of the party form and the increasingly unmediated relationship between unions and the working class (Audoin et al. 2001). It is significant that Castoriadis, whose project of autonomy has so many parallels with surrealism, was

${ }^{4}$ Exquisite Corpse is a very early surrealist discovery. Its simplicity means that it serves as an easy aid for the explication of surrealist games in general. However, it is important to note that it is atypical in that to the contemporary mind it seems little more than a parlour game. Although surrealist games can still be 'quick' in a similar vein to this one, they are frequently far richer and it is not at all unheard of for them to be played over a period of years or even decades.

${ }^{5}$ The Platform of Prague (Audoin et al. 2001) was a major collective text outlining the shared project of the surrealist groups in Paris and in Prague in 1968. It is significant not only because it was at that time the most substantial international collective declaration that the movement had produced but also because it was year of the Soviet invasion of Czechoslovakia and heralded a long period of clandestine organising for the Prague group which made further outside communication difficult. 
also at this time arguing in favour of this move in the form of a support for Council Communism -often under the pseudonym Paul Cardan as part of the group Socialisme ou Barbarie (For example in Castoriadis 1992).

In the Second Manifesto surrealism's early use of dialectical materialism is full of playful possibility. In critical modification of the explication of the negation of the negation provided by Engels (who he very much admired), Breton tells us

\footnotetext{
'There was, for us too, the necessity to put an end to idealism properly speaking, the creation of the word "Surrealism" would testify to this, and to quote Engels' classic example once again, the necessity not to limit ourselves to the childish: "The rose is a rose. The rose is not a rose. And yet the rose is a rose," but, if one will forgive me the parenthesis, to lure "the rose" into a movement pregnant with less benign contradictions, where it is, successively, the rose that comes from the garden, the one that has an unusual place in a dream, the one impossible to move from the "optical bouquet," the one that can completely change its properties by passing into automatic writing, the one that retains only those qualities that the painter has deigned to keep in a Surrealist painting, and, finally, the one, completely different from itself, which returns to the garden' (Breton 2007,141)
}

The key word here is 'lure'. Social movement in surrealism is neither the transitional movement of orthodox Leninism nor the appeal to the external (or the pure) that underlies Nihilism. Instead it uses social imaginary significations and institutions (in which we might include symbols, categories, and existing organisational forms) to lure and push into the unknown. Not transition but magnetism, understood as both an attractive and a repellent force.

Taking these methods out of the poetic and into the political requires a concentration on the element of surrealist gameplay that relies on collective (or 
individual) others to effect this luring out. Breton's specific employment of myth and Luca and Trost's development of Love as a political concept can help to get us there.

\title{
Becoming Great Transparent Ones
}

\footnotetext{
'A new myth? Must these beings be convinced that they result from a mirage or must they be given a chance to show themselves?' (Breton 2007, 294)
}

\begin{abstract}
Almost as a postscript to his Prolegomena to a Third Surrealist Manifesto, Breton introduces a myth: that of 'The Great Transparent Ones'. His page and a half long account describes an order of beings able to 'completely escape man's sensory system of references' (ibid. 293). This mythic construction belongs to the same category as those we have discussed above. It relies on the production of a sense of eeriness, the idea that one is in the proximity of something that one cannot see by conventional means. This is neither a story meant for the purposes of entertainment nor a statement of
\end{abstract} scientific speculation. It is rather an attempt to construct a new myth that is revealing of processes of social transformation of which surrealism is a methodological manifestation. The wording in the question above is telling. Breton is not enquiring as to whether we might create and/or uncover the great transparent ones. He is enquiring as to whether they might be 'given a chance to show themselves'. Once again, the thread that carries us through our discussion of negative capability and eeriness to this present point is the idea that the task is not to design the new and then move into it but to create the conditions from which the new might emerge. As such we might read Breton's formless creatures as personifications (or animations) of objective chance: the nonhuman element upon which social transformation rests. As we have seen though, in the 
surrealist game model this non-human element is still frequently mediated by other humans: the idea that within that game the collectivity itself is the source of objective chance. What Breton is proposing is a mythical being that one might become and unbecome, move in and out of.

Although building from the same raw materials, Luca and Trost (sometimes referred to as the Romanian Surrealist Group despite the fact that there were never more than two of them) take us back out of the mythic and into a slightly more recognisable realm of revolutionary politics. In their seminal tract Dialectics of the Dialectic, first published in $1945^{6}$, they reaffirm the importance of objective chance, whilst arguing for the historical specificity of surrealist technique in order to rail against the transformation of 'objective discoveries into means of artistic production' via which the process of surrealist research is turned into surrealist mannerism and its recuperation as an art movement cemented (Luca \& Trost 2001, 35). This call for the historic contextuality of surrealist practices can be seen as a recognition that methodologies of decomposition themselves become entrenched, losing their ability to draw the eye towards other space: 'We recognise in this dialectical attitude the most concrete possibility of keeping intact within ourselves the revolutionary mechanism and the means to trample underfoot any discovery that does not immediately oblige us to find another' (ibid., 36).

Luca and Trost's most significant development, though, is their identification of love, which they see as produced by objective chance, as the basis of a 'general revolutionary method' (ibid., 38). This is the foundation of what they describe as a

\footnotetext{
${ }^{6}$ Luca and Trost's development of 'non-oedipal' dialectics in this text and elsewhere was an important influence on Deleuze who has written on Luca in several published works (see Deleuze 1997, Deleuze and Guattari 1986, and Deleuze and Parnet 2007 for example).
} 
'revolution against nature' (ibid.) that we could very easily translate into Ungerian terms as a revolution against false necessity. They develop this revolutionary methodology of love through the concept of a non-Oedipal dialectic: 'The qualitative transformation of love into a general revolutionary method [...] [is] prevented by this primordial theoretical defeat maintained within us by the Oedipal position' (ibid.). For Luca and Trost, the removal of the Oedipal constraint, which they hope will lead to the 'unlimited eroticisation of the proletariat' (ibid., 37), is not a project of radical psychology (indeed they specifically talk of the need to free it from that terrain). Instead it is the basis of both thought and action aimed at the removal of the symmetrical negation that sees the proletariat producing itself in the bourgeoisie and vice versa. Crucially, it is a politics developed around desire that does not only relate to fundamental needs but is something 'we must labour to invent' (ibid., 36)

We can read Luca and Trost's project to produce a non-Oedipal model of love as being related to Spinoza's concept of love as power/capacity to act (which he refers to as Joy) 'accompanied by the idea of an external cause' (Spinoza 1992, 142). For Spinoza, that external cause is God. Returning to the Žižekian critique we encountered earlier in the article we see that the external cause for him is The Party. For Luca and Trost through, the external cause is objective chance itself, a new orbital centre of revolutionary organisation that does not, and cannot, stay still.

In this conception of love we find the clearest suggestion thus far of the sort of political organisation capable of facilitating the perpetual transformative movement of decomposition and recomposition. Luca and Trost's love is the organisation of chance encounters on a colossal scale. It is a model deliberately designed to be scalable; from the small-group experimentation introduced to us by Aragon to global emancipation of the proletariat. The form of organisation it suggests cannot be a massifying one since to 
massify is to gradually diminish the possibility of chance encounters with an other by absorbing that other. It is therefore also to erode the collective negative capability of the participants. Instead this suggests organisation that has as its basis the co-ordination of productive difference. Necessarily this is a democratic approach to which autocracy (be it the autocracy of a leader or that of an immovable set of ideas or ethics) is anathema. It is a particular type of democracy though: one which, whilst looking for commonalities, nurtures and preserves the island evolution of different communities-in-struggle so that encounters are always for the first time irrespective of whether they are in fact between the same individual actors. This is not a politics of unity but of intersubjectivity and intersectionality.

\section{Corbynmania and decomposition}

I want to finish by considering two contemporary examples of political organisation that relate, though do not necessarily conform, to this model. The first is that of the dissolution of the Class War organisation in 1997 of which we have some detail thanks to materials published at the time and subsequent recollections by the writing group the Free Association (made up by several of its former members). The second is the Corbynmania phenomenon that I have referred to previously. About this, we can only offer plausible and productive speculation.

Although there have been a number of more or less successful, somewhat nostalgic attempts to restart the organisation Class War, it folded as a large scale organisation in 1997. Four out of five of the writers who make up the Free Association had been part of the group arguing for dissolution and remember it thusly: 
' It had outlived its usefulness and was unable to relate to exciting new forms of struggle, such as the anti-roads movement $[\ldots]$ The orthodox left's failure to comprehend these new struggles seemed to be based in its prioritsing of identity over practice. Thus a few in Class War championed lorry drivers over anti-roads protesters, since the former were 'working class', whilst the latter were 'middleclass students'. They did not see the importance of transport in general, and roads in particular, to capitalist restructuring (neoliberalism). They therefore found it hard to understand that the doing of opposing new roads was a directly anti-capital doing' (Free Association 2011, 23-24)

What is significant about the decomposition of Class War is that it was both collective and deliberate rather than a gradual crumbling born of individual members leaving in dribs and drabs. Neither does it appear as a despairing throwing of the hands in the air and retreating grumpily until such time as society is ready to accept their truth. Instead, this group recognised an other who had evolved in a separate sphere but with whom they shared a common problematic, or in other words, common game parameters. Further, they recognised that Class War's development into a body that massified around identity meant that a productive encounter with this other was prevented from happening. As the body itself was unable to change, the degree to which it could facilitate negative capability was atrophied. However, the dissolvers were able to use this new political other - co-participants in same game - to lure themselves and the other constituted by the anti-roads movement out onto a wholly new terrain. Just as the surrealist game must, this constituted a real transformation: in this case the beginnings of the Alter-globalisation movement in the UK.

Contrastingly, it is too early to make confident analyses of the new sort of organisation, the new forms of movement evidenced by the (perhaps temporary, perhaps not) flocking to the Labour Party that the leadership election of the summer of 2015 has 
brought. But let us at least test this phenomenon against some of the methodologies we've discussed. Leaving aside obvious jokes about parliamentary politics making you 'sleepy - but not too sleepy to keep your eyes open' as is the requirement of Carroll's $(1987,338)$ eeriness, there is still something of the surrealist game of chance and of Unger's negative capability evidenced here. Much was made by Jeremy Corbyn's rivals in the Labour Party leadership election and by their supporters about the supposed archaism evidenced in his social and economic policies, which they identified as drawing heavily on post-WWII Keynesianism (amongst countless examples see Kendall quoted in Wintour 2015). This observation is entirely reasonable but what has been significant in its absence has been a groundswell of Corbynmaniacs arguing for the same specific policies. It is plausible then that the overwhelming support he has received is not evidence of a broad-based desire to return to a time before neoliberal restructuring but of something else. Cautiously, we might propose that the Corbyn's role is as a vessel of objective chance. He has been introduced into the game (not by himself but by the movement of which he has been a part) not because Keynesianism must once again replace neoliberalism but in order to break apart (decompose) the cross-parliamentary clog represented by austerity neoliberalism. If this is successful (and it could easily not be) it will shift social relations onto a brand new terrain that neither Corbyn nor anyone else could imagine or design in advance.

Corbynmania definitely represents at some level a decomposition of the Labour party. It's too early to say whether that decomposition will accelerate or not and whether, should it go full blown, we will see the party cease to exist or whether it will 
transform within its shell like an insect passing through instars ${ }^{7}$. Whatever the outcome, it is inevitable that the loss of the older form will be mourned. However, it should not be. If the new politics, of which Corbynmania is but one expression, is one based around the production of encounters rather than massification, then it may well provide real hope of genuine social transformation, genuine movement.

\section{References}

Aragon, Louis. 2003. 'A Wave of Dreams' Papers of Surrealism. 1(1): 1-12, accessed July $2^{\text {nd }} 2015$.

http://www.surrealismcentre.ac.uk/papersofsurrealism/journal1/index.htm Audoin, Philippe, Jean-Loius Bédouin, Robert Benayoun, Jean Benoît, Micheline Bounoure, Vincent Bounoure, Guy Cabanel et al. 2001. 'The Platform of Prague' in Surrealism Against the Current: Tracts and Declarations edited by Michael Richardson and Krzysztof Fijalkowski, 58-66, London: Pluto Press bamn Editorial Group. 2015. 'Austerity is Over. If we want it' bamn 1 (1.5): 1.

Bataille, Georges. 2006. The Absence of Myth: Writings on Surrealism. London: Verso Critchley, Simon. 2013. 'Introduction' in Anarchist Turn edited by Jacob Blumenfeld, Chiara Bottici, and Simon Critchley, 7-14. London: Pluto Press.

Breton, André. 2007. Manifestoes of Surrealism Ann Arbor: University of Michigan Press.

Brown, Gareth, Emma Dowling, David Harvie and Keir Milburn. 2013. 'Careless Talk: Social Reproduction and Fault Lines of the Crisis in the United Kingdom' Social Justice. 39 (1): 78-98

Carroll, Lewis. 1987. The Complete Illustrated Works of Lewis Carroll. London: Chancellor Press.

Castoriadis, Cornelius. 1987. The Imaginary Institution of Society, London: Polity.

\footnotetext{
${ }^{7} \mathrm{An}$ instar is a stage of insect development. Passing from one instar to the next requires a period of pupation during which the body is deconstructed and reconstructed as part or a process of full or partial metamorphosis.
} 
Castoriadis, Cornelius. 1991. 'Power, politics, autonomy'. in Philosophy, Politics, Autonomy: Essays in Political Philosophy. Oxford: Oxford University Press.

Castoriadis, Cornelius. 1992. The Revolutionary Project. Philadelphia: Philadelphia Solidarity

Castoriadis, Cornelius. 1997. 'Radical Imagination and the Social Instituting Imaginary' in The Castoriadis Reader, Oxford: Blackwell

Corbin, Henry. 1964. 'Mundus Imaginalis: of The Imaginary and the Imaginal' Hermetic.com. Accessed $17^{\text {th }}$ November 2011. http://hermetic.com/bey/mundus_imaginalis.htm

Deleuze, Gilles. 1997. Essays Critical and Clinical. Minneapolis: University of Minnesota Press.

Deleuze, Gilles, and Felix Guattari. 1986. Kafka: Towards a Minor Literature. Minneapolis: University of Minnesota Press.

Deleuze, Gilles, and Felix Guattari. 2003. Anti-Oedipus: Capitalism and Schizophrenia. London: Continuum.

Deleuze, Gilles, and Guattari, Felix. 2004. A Thousand Plateaus: Capitalism \& Schizophrenia. London: Continuum.

Deleuze, Gilles, and Claire Parnet. 2007. Dialogues II, New York: Columbia University Press

Fish, Stanley. 1990. 'Unger and Milton' in Doing What Comes Naturally: Change, Rhetoric, and the Practice of Theory in Literary and Legal Studies. Oxford: Oxford University Press.

The Free Association. 2011. 'What is the movement?' in Moments of Excess: Movements, protest and everyday life. Oakland. PM Press.

Freud, Sigmund. 1962. Beyond the Pleasure Principle, Group Psychology, and Other Works, SE XVIII, London: Hogarth Press

Haiven, Max. 2014. Crises of Imagination, Crises of Power: Capitalism, Creativity, and Commons London \& New York: Zed Books

The Institute for Precarious Consciousness. 2014. 'We Are All Very Anxious' Accessed April $22^{\text {nd }} 2014$ at http://www.weareplanc.org/we-are-all-very-anxious Jepps, Jim. 2013. 'Five things I learned when leaving the SWP' The Nice Badge Man October 23. http://www.jimjepps.net/five-things-i-learned-when-leaving-the$\mathrm{swp} /$ 
Joffe, Deb. 2015. 'Why Corbynmania is a win for the Green Party' Bright Green July 28. http://bright-green.org/2015/07/28/why-corbynmania-is-a-win-for-the-greenparty/

Keats, John. 1968. Selected Poems \& Letters of Keats London: Heinemann

Lautréamont, Comte De. 1998. Maldoror \& The Complete Works. Cambridge: Exact Change

Luca, Gerashim, and Trost. 2001. 'Dialectics of the Dialectic: A Message Addressed to the International Surrealist Movement' in Surrealism Against the Current: Tracts and Declarations edited by Michael Richardson and Krzysztof Fijalkowski, 32-41 London: Pluto Press

Milburn, Keir. 2010. The Organisation of Excess: Movement, Analysis and Alterglobalisation. PhD diss., University of Leeds.

Nunes, Rodrigo. 2013. Organisation of the Organisationless: The Question of Organisation After Networks. Berlin/Lüneberg: Mute/PML

Socialist Worker Party. 'SWP conference minority position and reply by Central Committee' Accessed April 22 2014. http://www.marxsite.com/SWP\%20debate.htm

Sparrow, Andrew \& Rowena Mason. 2015, 'Labour identifies Green candidates trying to vote in its leadership election' The Guardian. August 12. http://www.theguardian.com/politics/2015/aug/12/green-candidates-caughttrying-to-sign-up-to-vote-in-labour-party-leadership-contest'

Spinoza, Baruch. 1992. Ethics: Treatise on The Emendation of the Intellect and Selected Letters, Indianapolis: Hackett

Steel, Mark. 2013. 'Oh Good Lord. What has the SWP gone and done NOW?' Mark Steel May 13. http://marksteelinfo.com/oh-good-lord-what-has-the-swp-goneand-done-now/

Townsend, Esther. 2013. 'The Socialist Party, Steve Hedley, and domestic violence: stop evading, stop lying' Women's Fightback December 24. https:/womensfightback.wordpress.com/2013/12/24/the-socialist-party-stevehedley-and-domestic-violence-stop-evading-stop-lying/

U.K. Government. 2012. Membership of UK Political Parties. McGuinness, Feargal. London: House of Commons Library.

U.K. Government. 2013. Department for Business and Innovation Skills. Trade Union Membership 2012: Statistical Bulletin. London. 
Unger, Roberto Mangabeira. 2001. False Necessity: Anti-Necessitarian Social Theory in the Service of Radical Democracy (Politics Vol. 1). London: Verso.

Wintour, Patrick. 2015. 'Jeremy Corbyn confident that Labour will unite around him if he wins' The Guardian. September 11.

http://www.theguardian.com/politics/2015/sep/10/jeremy-corbyn-confidentlabour-will-unite-around-him-if-he-wins

Žižek, Slavoj. 2003. Organs Without Bodies: Deleuze and Consequences. London:

Routledge 